REVIEW

\title{
Further delineation of the MECP2 duplication syndrome phenotype in 59 French male patients, with a particular focus on morphological and neurological features
}

Marguerite Miguet, ${ }^{1}$ Laurence Faivre, ${ }^{2}$ Jeanne Amiel, ${ }^{3}$ Mathilde Nizon, ${ }^{3}$

Renaud Touraine, ${ }^{4}$ Fabienne Prieur, ${ }^{4}$ Laurent Pasquier, ${ }^{5}$ Mathilde Lefebvre, ${ }^{2}$

Julien Thevenon, ${ }^{2}$ Christèle Dubourg, ${ }^{6}$ Sophie Julia, ${ }^{7}$ Catherine Sarret, ${ }^{8}$

Ganaëlle Remerand, ${ }^{8}$ Christine Francannet, ${ }^{9}$ Fanny Laffargue, ${ }^{9}$

Odile Boespflug-Tanguy, ${ }^{10}$ Albert David, ${ }^{11}$ Bertrand Isidor, ${ }_{1}^{11}$ Jacqueline Vigneron, ${ }^{12}$

Bruno Leheup, ${ }^{12}$ Laetitia Lambert, $^{12}$ Christophe Philippe, $^{13}$ Mylène Béri-Dexheimer, $^{13}$

Jean-Marie Cuisset, ${ }^{14}$ Joris Andrieux, ${ }^{15}$ Ghislaine Plessis, ${ }^{16}$ Annick Toutain, ${ }^{17}$

Laurent Guibaud, ${ }^{18}$ Valérie Cormier-Daire, ${ }^{3}$ Marlene Rio, ${ }^{3}$ Jean-Paul Bonnefont, ${ }^{19}$

Bernard Echenne, ${ }^{20}$ Hubert Journel, ${ }^{21}$ Lydie Burglen, ${ }^{22}$ Sandrine Chantot-Bastaraud, ${ }^{22}$

Thierry Bienvenu, ${ }^{23}$ Clarisse Baumann, ${ }^{24}$ Laurence Perrin, ${ }^{24}$ Séverine Drunat, ${ }^{25}$

Pierre-Simon Jouk, ${ }^{26}$ Klaus Dieterich, ${ }^{26}$ Françoise Devillard, ${ }^{26}$ Didier Lacombe, ${ }^{27}$

Nicole Philip, ${ }^{28}$ Sabine Sigaudy, ${ }^{28}$ Anne Moncla, ${ }^{29}$ Chantal Missirian, ${ }^{29}$

Catherine Badens, ${ }^{30}$ Nathalie Perreton, ${ }^{31}$ Christel Thauvin-Robinet, ${ }^{2}$

Réseau AChro-Puce, ${ }^{32}$ Jean-Michel Pedespan, ${ }^{33}$ Caroline Rooryck, $^{27}$ Cyril Goizet, $^{27}$

Catherine Vincent-Delorme, ${ }^{34}$ Bénédicte Duban-Bedu, ${ }^{35}$ Nadia Bahi-Buisson, ${ }^{36}$

Alexandra Afenjar, ${ }^{37}$ Kim Maincent, ${ }^{37}$ Delphine Héron, ${ }^{38}$ Jean-Luc Alessandri, ${ }^{39}$

Dominique Martin-Coignard, ${ }^{40}$ Gaëtan Lesca, ${ }^{41,42}$ Massimiliano Rossi, ${ }^{41,42}$

Martine Raynaud, ${ }^{43}$ Patrick Callier, ${ }^{44}$ Anne-Laure Mosca-Boidron, ${ }^{44}$ Nathalie Marle, ${ }^{44}$

Charles Coutton, ${ }^{45}$ Véronique Satre ${ }^{45}$ Cédric Le Caignec, ${ }^{46,47}$ Valérie Malan, ${ }^{48}$

Serge Romana, ${ }^{48}$ Boris Keren, ${ }^{49}$ Anne-Claude Tabet, ${ }^{50}$ Valérie Kremer, ${ }^{51}$

Sophie Scheidecker, ${ }^{51}$ Adeline Vigouroux, ${ }^{52}$ Marilyn Lackmy-Port-Lis, ${ }^{53}$

- Additional material is

published online only. To view, please visit the journal online (http://dx.doi.org/10.1136/ jmedgenet-2017-104956).

For numbered affiliations see end of article.

Correspondence to Dr Salima El Chehadeh, Service de génétique médicale, Hôpitaux Universitaires de Strasbourg, Hôpital de Hautepierre, Strasbourg 67098 France; salima.elchehadeh@ chru-strasbourg.fr

Received 6 September 2017 Revised 4 February 2018 Accepted 15 February 2018 Published Online First 4 April 2018

Check for updates

To cite: Miguet $M$, Faivre $L$, Amiel J, et al. J Med Genet 2018:55:359-371.

Damien Sanlaville, ${ }^{54}$ Marianne Till, ${ }^{54}$ Maryline Carneiro, ${ }^{55}$ Brigitte Gilbert-Dussardier, ${ }^{56}$ Marjolaine Willems, ${ }^{57}$ Hilde Van Esch, ${ }^{58}$ Vincent Des Portes, ${ }^{59,60}$ Salima El Chehadeh ${ }^{1,2}$

\section{ABSTRACT}

The Xq28 duplication involving the MECP2 gene (MECP2 duplication) has been mainly described in male patients with severe developmental delay (DD) associated with spasticity, stereotypic movements and recurrent infections. Nevertheless, only a few series have been published. We aimed to better describe the phenotype of this condition, with a focus on morphological and neurological features. Through a national collaborative study, we report a large French series of 59 affected males with interstitial MECP2 duplication. Most of the patients $(93 \%)$ shared similar facial features, which evolved with age (midface hypoplasia, narrow and prominent nasal bridge, thick lower lip, large prominent ears), thick hair, livedo of the limbs, tapered fingers, small feet and vasomotor troubles. Early hypotonia and global DD were constant, with $21 \%$ of patients unable to walk. In patients able to stand, lower limbs weakness and spasticity led to a singular standing habitus: flexion of the knees, broadbased stance with pseudo-ataxic gait. Scoliosis was frequent $(53 \%)$, such as divergent strabismus (76\%) and hypermetropia (54\%), stereotypic movements (89\%), without obvious social withdrawal and decreased pain sensitivity (78\%). Most of the patients did not develop expressive language, 35\% saying few words. Epilepsy was frequent (59\%), with a mean onset around 7.4 years of age, and often (62\%) drug-resistant. Other medical issues were frequent: constipation (78\%), and recurrent infections (89\%), mainly lung. We delineate the clinical phenotype of MECP2 duplication syndrome in a large series of 59 males. Pulmonary hypertension appeared as a cause of early death in these patients, advocating its screening early in life.

\section{INTRODUCTION}

The MECP2 gene encodes an essential epigenetic regulator in postnatal brain development involved in transcriptional activation as well as repression of many genes. ${ }^{1-3}$ Loss of function mutations of MECP2 in females result in classic Rett syndrome, 
a progressive childhood neurodevelopmental disorder, while hemizygous mutations found in males are often lethal. ${ }^{4}$ Different MECP2 pathogenic variations have also been described in male patients with a phenotype ranging from severe neonatal encephalopathy to non-specific moderate intellectual disability (ID). ${ }^{56}$ An increased dosage of methyl-CpG binding protein-2 (MeCP2) resulting from a duplication of the $\mathrm{Xq} 28$ region including MECP2 (MECP2 duplication) (MIM 300260), leads to a severe neurodevelopmental disorder in males. ${ }^{7-9}$ This disorder generally includes early hypotonia, progressive lower limbs spasticity, very poor to absent speech, severe epilepsy, stereotypic movements and recurrent infections. Since the initial report, around 160 male patients have been reported. This has led to the description of a clinically recognisable syndromic ID. ${ }^{10-12}$ It has been shown that a small proportion of carrier females could be symptomatic, with a non-specific and mild developmental delay (mostly) or a severe phenotype ${ }^{13-17}$ In a previous study, we reported a series of 20 symptomatic females carrying a de novo interstitial MECP2 duplication (6 novel and 14 reported patients). Thirty-seven per cent had inherited their duplication from their mother, including three mildly, one moderately and three severely affected patients. No correlation was shown between X chromosome inactivation (XCI) in the blood or duplication size and the severity of the phenotype. These findings confirmed that an abnormal phenotype, even severe, can be a rare event in females born to asymptomatic carrier mothers, making genetic counselling difficult in couples at risk. ${ }^{17}$

Previous studies in mice also showed that MECP2 dosage plays a major role in postnatal neurodevelopment. Mice with twice the endogenous level of MeCP2 appear normal until 10-12 weeks of age, after which they display forepaw stereotypies, impaired coordination, seizures, hypoactivity and spasticity. ${ }^{18}$ It has also been shown that increased MeCP2 dosage in mice leads to increased synaptic numbers, having therefore a major impact on the formation of excitatory synapses. ${ }^{19}$ In the same way, it has been elegantly demonstrated that cortical neurons derived from different induced pluripotent stem cells (iPSC) lines of patients with MECP2 duplication syndrome have increased synaptogenesis and dendritic complexity and that their neuronal network synchronisation was altered. ${ }^{20}$ These findings contribute to the understanding of the underlying pathways that lead to the very severe neurodevelopmental phenotype of this disease. Furthermore, a more recent study showed that antisense oligonucleotides treatment could rescue many features in adult symptomatic transgenic MECP2 duplication mice, which appears to be a very promising therapeutic approach. ${ }^{21}$

Although the size of the duplications differs from one patient to another, and despite the involvement of several other brain-expressed genes than MECP2, such as SLC6A8 (MIM 300036), L1CAM (MIM 308840), FLNA (MIM 300017) and GDI1 (MIM 300104)-which are responsible for various neurodevelopmental disorders-it has been demonstrated that the increased dosage of $M E C P 2$ is sufficient to explain the core phenotype of MECP2 duplication syndrome. ${ }^{10}$ Indeed, several affected patients harbouring the smallest duplications, only including IRAK1 and MECP2, presented with developmental delay, epilepsy, spasticity and recurrent lung infections. ${ }^{822} 23$

The exact prevalence of MECP2 duplication syndrome remains unknown, although different screening attempts have estimated that it may explain about $1 \%$ of severe X-linked intellectual disability (XLID) cases. ${ }^{24}$ Very few large series have been reported to date, in particular those regarding the morphological phenotype. Following active data collection from 24 different French clinical genetic departments and 17 cytogenetic and molecular laboratories, we now report a large French series of affected males with an intrachromosomal Xq28 duplication involving MECP2. We describe the clinical phenotype with a focus on the morphological and neurological features of this disorder. We also review the patients reported to date in the literature and report more clinical features.

\section{PATIENTS AND METHODS Data collecting}

Patients carrying an Xq28 duplication involving MECP2 (MECP2 duplication) were recruited through a French collaborative study conducted from 2012 to 2016, for phenotypical delineation and genotype-phenotype correlation purposes (XLID Research Project 2008-2016, French Ministry of Health). For each patient included, medical data were taken both retrospectively from medical records and as far as possible, cross-sectionally during a dedicated medical consultation. During the latter, the physician asked the parents about the medical history (including the motor skills, behaviour, way of life, kinds of re-education, etc), performed a clinical examination, filled out a detailed questionnaire and took morphological pictures. Since most of the patients have a poor intellectual functioning, no standardised psychometric test could be performed. The degree of ID was determined on the basis of adaptive skills (ambulation, motor development, communication, sociability, daily life autonomy), in accordance with the Diagnostic and Statistical Manuel of mental Disorders, fifth edition. ${ }^{25}$ Additional investigations were only performed if beneficial for the patient, accounting for missing clinical and radiological data.

\section{Cytogenetic and molecular analyses}

The duplications were detected using a pangenomic (Array Comparative Genomic Hybridization (Array-CGH)) or a targeted approach (Multiplex Ligation-dependent Probe Amplification (MLPA) or quantitative PCR (qPCR) analyses), which were performed in 16 French cytogenetic and molecular laboratories and one Belgian laboratory (Leuven). They were performed on genomic DNA isolated from peripheral blood samples. Regarding Array-CGH, the platform used for most of the patients was the Human Genome CGH Microarray $150 \mathrm{~K}$ or $180 \mathrm{~K}$ from Agilent according to the manufacturer's protocol (Agilent Technologies, Santa Clara, California, USA). MLPA was performed using the method described by Schouten et al in case the clinicians suspected the MECP2 duplication syndrome. ${ }^{26}$ The duplications were confirmed by fluorescence in situ hybridization (FISH) with various specific probes on chromosome preparations from leucocyte cultures or by qPCR using standard protocols. Parental analyses were performed using FISH or qPCR. Genomic positions were relative to human genome GRCH37/hg19.

All patients' families provided written informed consent and all procedures performed in the studies were done in accordance with the ethical standards of the institutional research committee and with the Declaration of Helsinki.

\section{RESULTS}

\section{Study population}

One hundred and one cases, including 91 males and 10 females (including twins), were identified with a MECP2 duplication in the context of their diagnostic workup for ID. Among the 91 males, the duplications resulted from interstitial (intraC) Xq28 duplication in 86 cases (54 families) and from a complex chromosomal aberration, such as X-autosome translocation or insertion of the $\mathrm{Xq} 28$ region into an autosome, in five cases. Twenty-three out of 

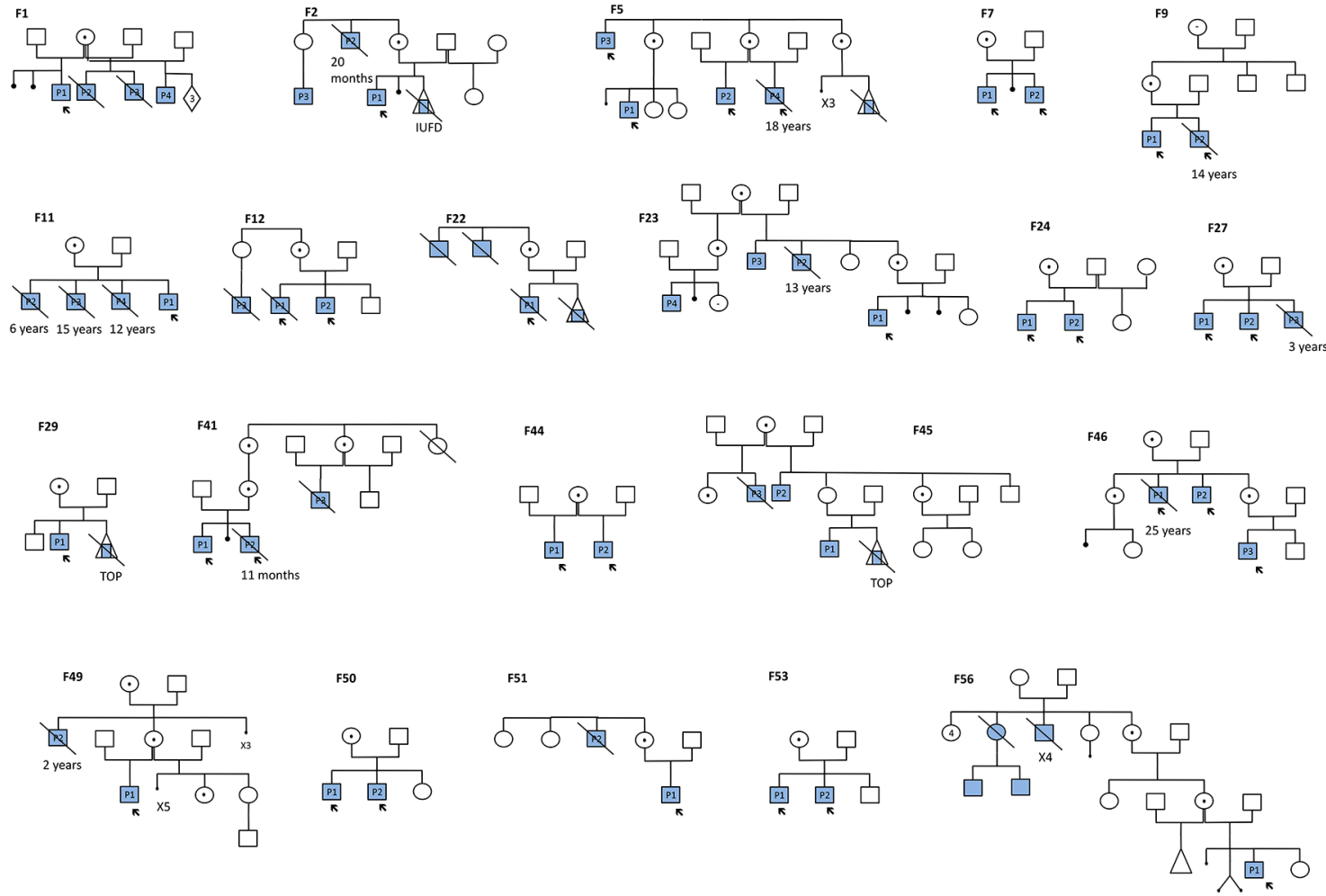

Figure 1 Family trees. The full squares represent the affected males

the 86 patients $(27 \%)$ died before the age of 25 years $(11$ months to 24 years, mean age: 9.5 years). Among the 11 patients for whom the cause of the death was known, 8 (73\%) died from respiratory infections, $2(18 \%)$ from a pulmonary hypertension and $1(9 \%)$ from status epilepticus. Seventy-three out of the 83 for whom we had the information (88\%), had inherited their duplication from their mothers. The pedigrees of the 19 families with an X linked inheritance are illustrated in figure 1 . The present study reports only on the 86 males with intraC MECP2 duplication, with a focus on the 59 patients for whom we were able to collect clinical and morphological data, including photographs. Twenty-five were examined by the same physician (SEC), which could help highlight recurrent clinical features that were often overlooked.

\section{Cytogenetic and molecular data}

Duplications were detected using genomic microarrays in 25 out of the 54 families (46\%) and targeted analysis in 29/54 families (54\%). The analysis of the 46 families in which the duplication breakpoints were available showed that the Xq28 duplications were different in size and breakpoint between patients as illustrated in online supplementary figure 1 . We observed a recurrent distal breakpoint in nine patients (153609163 bp) suggesting a susceptibility region in Xq28 to such a rearrangement, and 85\% (39/46) of the duplications shared a common region of $1.5 \mathrm{Mb}$ located between position 152485412 and position 153949811 (hg19) (online supplementary figure 1 and table 1). The mean size of the duplications was $1856 \mathrm{~kb}$ (range: 102-16704kb), and the main genes included in the duplications were MECP2, IRAK1, GDI1, FLNA and L1CAM. Since the patients with the smallest duplications did not have a milder neurological phenotype, we could not show an obvious correlation between the size of the duplications and the severity of the phenotype. The FMR1 gene was involved only in the three patients harbouring the largest duplications (online supplementary figure 1 and table 1). XCI studies showed that all of the carrier mothers for whom data were available had completely skewed XCI (XCI ratio > 80:20) (data not shown).

\section{Clinical data}

We were able to collect clinical data for 59 out of the 86 male patients harbouring an intraC MECP2 duplication. Among them, nine $(15 \%)$ died before the age of 25 years. The mean age at examination was 11.7 years (range: 2 months to 48 years), with 13 adult patients (age $\geq 18$ years). The clinical data are summarised in tables 1 and 2 and online supplementary table 2 .

\section{Perinatal period}

The mean term of birth was 39 weeks of gestation (WG) (range: $32-41)$. Four patients were born prematurely (<37 WG). Birth parameters were within the normal range with a mean weight at $-0.1 \mathrm{SD}$ score (SDS) ( $-2.6 \mathrm{SDS}$; +3.5 SDS), mean height at -0.7 SDS ( $-4.5 \mathrm{SDS} ;+1.9 \mathrm{SDS})$ and mean head circumference at +0.1 SDS $(-2.5$ SDS; +4.5 SDS). The Apgar score was abnormal $(<8)$ for $10 \%(5 / 50)$ of the newborns and $20 \%$ $(10 / 50)$ were admitted to either a neonatology department or an intensive care unit. Later, 55\% (32/58) of the patients had complications during the neonatal period, including early hypotonia $(11 / 58)$, feeding difficulties $(15 / 58)$ or infection $(4 / 58)$ (online supplementary table 2 ).

\section{Growth parameters and craniofacial features}

The growth parameters were mainly in the normal range. Mean occipitofrontal circumference (OFC) was +0.2SDS (-3.4 SDS; +4.8SDS). Four out of $53(8 \%)$ patients had microcephaly (OFC <-2 SDS) and 9/53 (17\%) were macrocephalic (OFC $>+2$ SDS) (table 1). The mean height was -0.4 SDS $(-5.2$ SDS; +2.8SDS) and the mean weight was +0.4SDS $(-4.7$ 
Table 1 Summary of the main facial and limb morphological features from the present cohort

\begin{tabular}{|c|c|c|}
\hline Main facial and limb features & Present & Percentage (\%) \\
\hline Midface hypoplasia & $42 / 45$ & 93 \\
\hline Microcephaly (OFC <-2 SDS) & $4 / 53$ & 8 \\
\hline Macrocephaly (OFC >+2 SDS) & $9 / 53$ & 17 \\
\hline \multicolumn{3}{|l|}{ Hair } \\
\hline Sparse anteriorly & $29 / 42$ & 69 \\
\hline Thick and dense & $39 / 43$ & 91 \\
\hline \multicolumn{3}{|l|}{ Eyes } \\
\hline Deep set eyes & $25 / 43$ & 58 \\
\hline Strabismus & $41 / 54$ & 76 \\
\hline Sparse eyebrows & $23 / 43$ & 54 \\
\hline Synophris & $11 / 43$ & 26 \\
\hline Epicanthus & $18 / 44$ & 41 \\
\hline Ptosis & $13 / 43$ & 30 \\
\hline Hypertelorism & $20 / 44$ & 45 \\
\hline \multicolumn{3}{|l|}{ Mouth and teeth } \\
\hline Open mouth appearance & $44 / 45$ & 98 \\
\hline Drooling & $40 / 50$ & 80 \\
\hline Small mouth & $32 / 46$ & 70 \\
\hline Thick lower lip & $36 / 46$ & 78 \\
\hline Prominent central incisors & $16 / 32$ & 50 \\
\hline Teeth anomalies & $32 / 34$ & 94 \\
\hline Persistence of deciduous teeth & $23 / 26$ & 88 \\
\hline \multicolumn{3}{|l|}{ Nose } \\
\hline Anteverted nostrils & $23 / 44$ & 52 \\
\hline Prominent nasal tip & $29 / 43$ & 67 \\
\hline Prominent nasal bridge & $32 / 42$ & 76 \\
\hline Narrow nasal bridge & $28 / 44$ & 64 \\
\hline \multicolumn{3}{|l|}{ Ears } \\
\hline Large prominent ears & $39 / 46$ & 85 \\
\hline \multicolumn{3}{|l|}{ Limbs } \\
\hline Small hands and feet & $21 / 34$ & 62 \\
\hline Tapered fingers & $36 / 39$ & 92 \\
\hline Vasomotor troubles & $15 / 31$ & 48 \\
\hline Livedo of the limbs & $34 / 39$ & 87 \\
\hline Valgus flat feet & $26 / 35$ & 74 \\
\hline
\end{tabular}

OFC, occipitofrontal circumference; SDS, SD score.

SDS; +5.9SDS) (table 2). Most of the patients had particular facial features (51/55), summarised in table 1 and illustrated in figures 2 and 3 . We noted that most of the affected males had a similar facial gestalt, characterised by a midface hypoplasia (93\%), deep set eyes (58\%), hypertelorism (45\%), a small (70\%) open mouth $(98 \%)$ with a thick lower lip $(78 \%)$ and intermittent drooling (80\%), large prominent ears $(85 \%)$, narrow $(64 \%)$ and prominent $(76 \%)$ nasal bridge with anteverted nostrils (52\%). Hair was often thick and dense (91\%) with a sparse area on the lateral part of the forehead (69\%) (figure 2, patients F53P2, F5P1, F55P1), which led to a temporal spike aspect, and the eyebrows were often sparse (54\%) (figure 2, patients F29P1, F40P1, F5P4) with a synophrys sometimes apparent (26\%). A bilateral epicanthus was noted in $41 \%$ of the patients. We noted that patients with a light skin phototype had particularly pale and bright blue eyes. Other recurrent features were dental shape and/or eruption abnormalities in $94 \%$ of the series, including prominent central incisors (50\%), and persistence of the deciduous teeth $(88 \%)$, often requiring multiple tooth extractions (table 1, figures 2 and 3 ).
We found that $62 \%$ of the patients had abnormally small feet which were often flat with a valgus deformation (74\%). The hands showed tapered fingers in 36/39 (92\%) patients and a camptodactyly of several fingers was noticed in few cases (figure 4B). Frequent vasomotor problems were noted (48\%) leading to moist and red hands and/or feet (figure 4C). We also noted an apparent venous network (livedo) of the limbs in 34/39 $(87 \%)$ of the children, which tended to be less evident after adolescence (figure 4D) (table 1).

Interestingly, in the 45 patients for whom photographs were available from early infancy $(<3$ years) to school age $(6-14$ years) or adulthood, we were able to observe, as often in syndromology, an evolution of the facial features with ageing. In early infancy, the face looked mostly round with a small chin and full cheeks and the mouth already appeared small, with downturned corners, a convex upper lip and open appearance with frequent drooling visible (figures 3 and 5). With time, the face became elongated, with a prominent chin and a larger mouth with sometimes prominent central incisors. The nose was initially particularly small with anteverted nostrils and changed with frequent prominent nasal bridge and tip. Facial features tended to become coarser and eyes appeared deeper after adolescence and during adulthood, although facial dysmorphism was very mild in some patients (figure 5).

\section{Hearing and vision}

Seven out of 23 (30\%) patients who were assessed had mild-tomoderate hearing loss (table 2). The type of the deafness was specified in three cases only (two patients had conductive deafness in a context of numerous otitis and one had perceptive deafness). A divergent strabismus was frequent $(41 / 54,76 \%)$ and could be related to visual impairment since 54\% (21/39) of the patients had hypermetropia. Three patients had corneal anomalies (scars and sclerocornea). A ptosis was noted in $30 \%$ of the patients.

\section{Neurodevelopmental and orthopaedic features}

During childhood, almost all patients had early hypotonia (57/58) (online supplementary figure 2) and all had global DD (59/59). Motor skills were severely affected as 12/56 (21 $\%)$ were unable to achieve ambulation without support. For the remaining patients, the mean age of independent walking was delayed (3.6 years (range: $1.8 ; 5.4)$ ). Among them, seven lost the ability to walk. Patients developed orthopaedic symptoms that could be, at least partially, the consequences of lower limbs spasticity and hypotonia. One of the main features was kyphoscoliosis, present in 53\% of them (23/43). Another striking feature was a lower limbs spasticity leading to a singular habitus with a flexion and sometimes contractures of the ankles, the knees and the trunk. This spasticity was not often associated with pyramidal signs as Babinski sign or hyper-reflexia but led to an abnormal pseudoataxic gait with a degree of instability and a broad-based stance (figure 4A, table 1). We hypothesise that this unstable gait is partly due to an abnormal development of the proprioceptive pathways. This leads to a shift of the centre of gravity of the body which is partially compensated by the flexion attitude.

\section{Epilepsy}

Seizures were seen in 59\% (35/59) of individuals with a mean onset around 7.4 years of age (0.4-35). Seizure types were generalised tonic-clonic seizures (19/35), absences (5/35), partial complex (6/35), atonic (12/35) and myoclonic seizures (8/35). Sixty-two per cent (21/34) had drug-resistant epilepsy. 


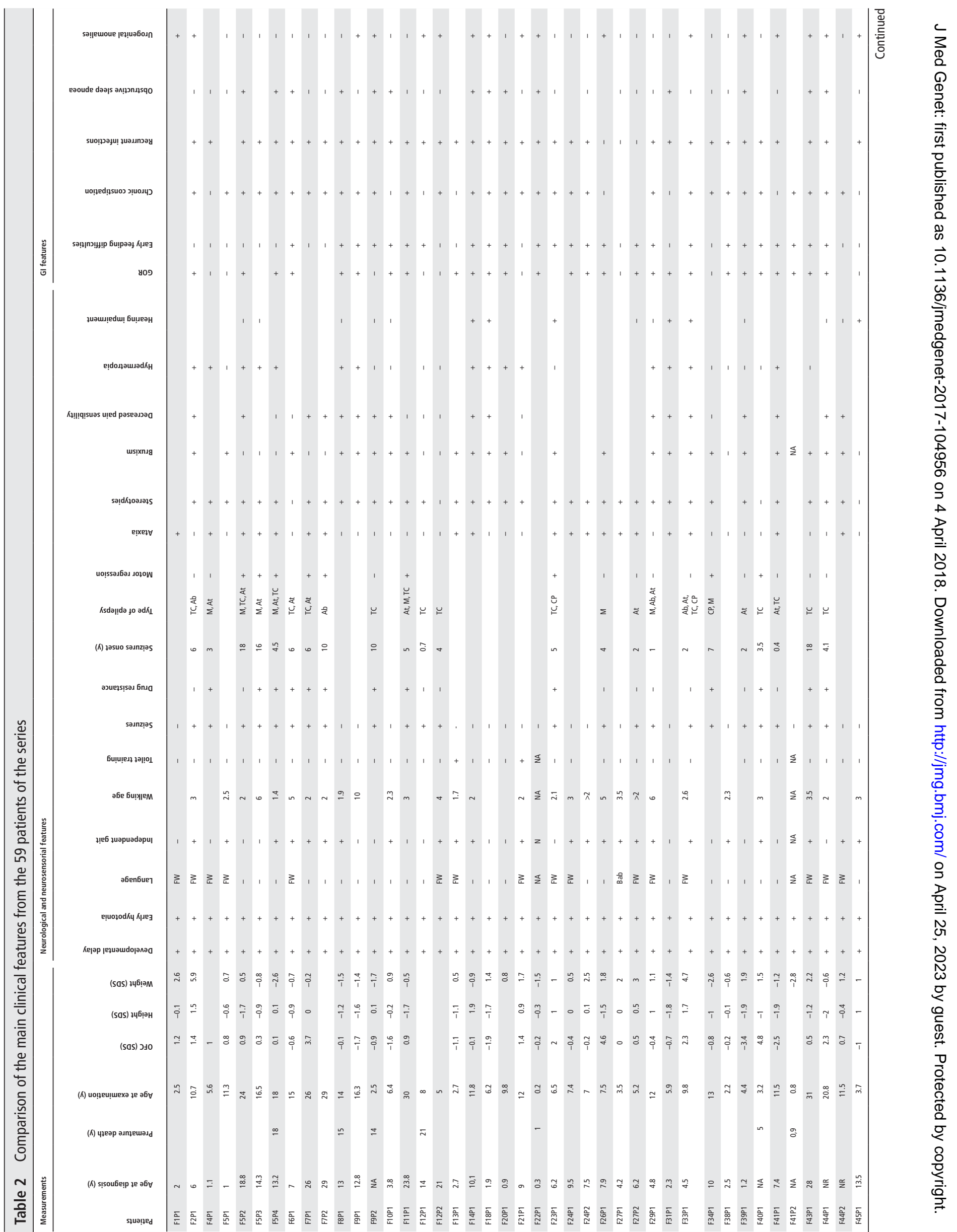




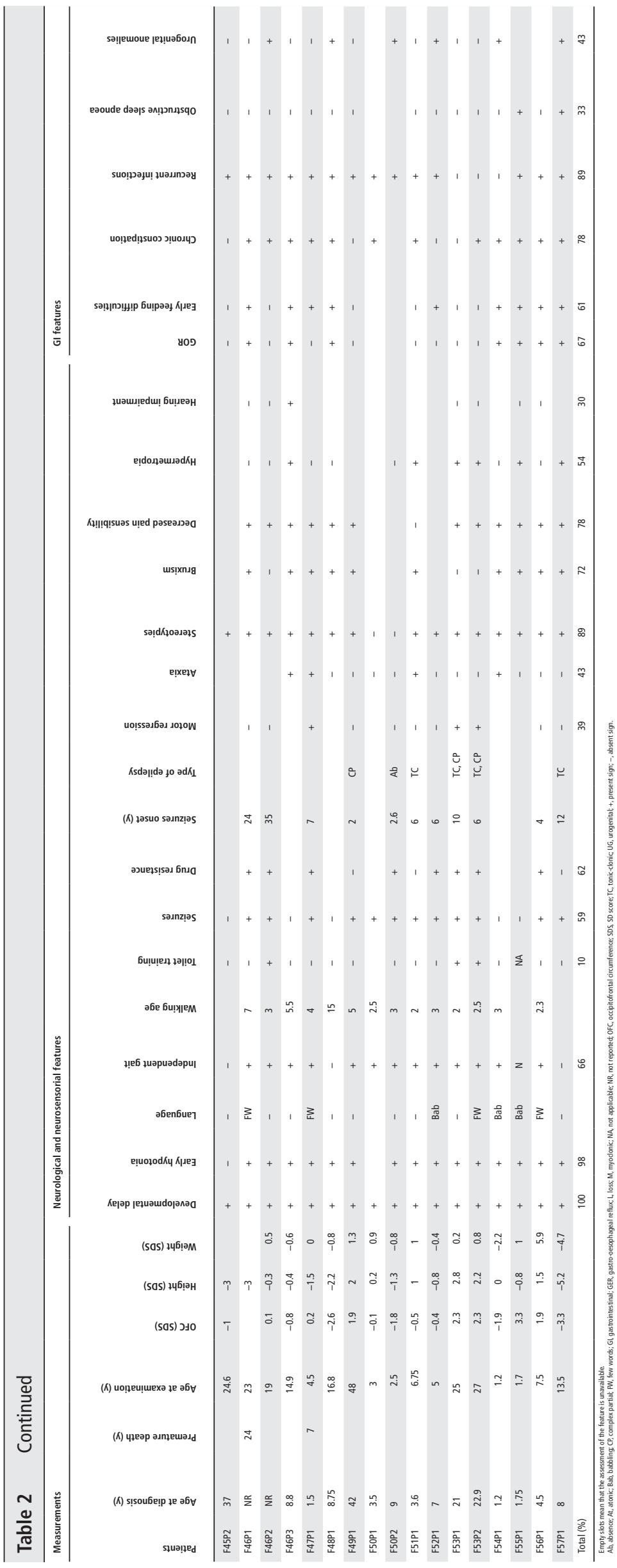




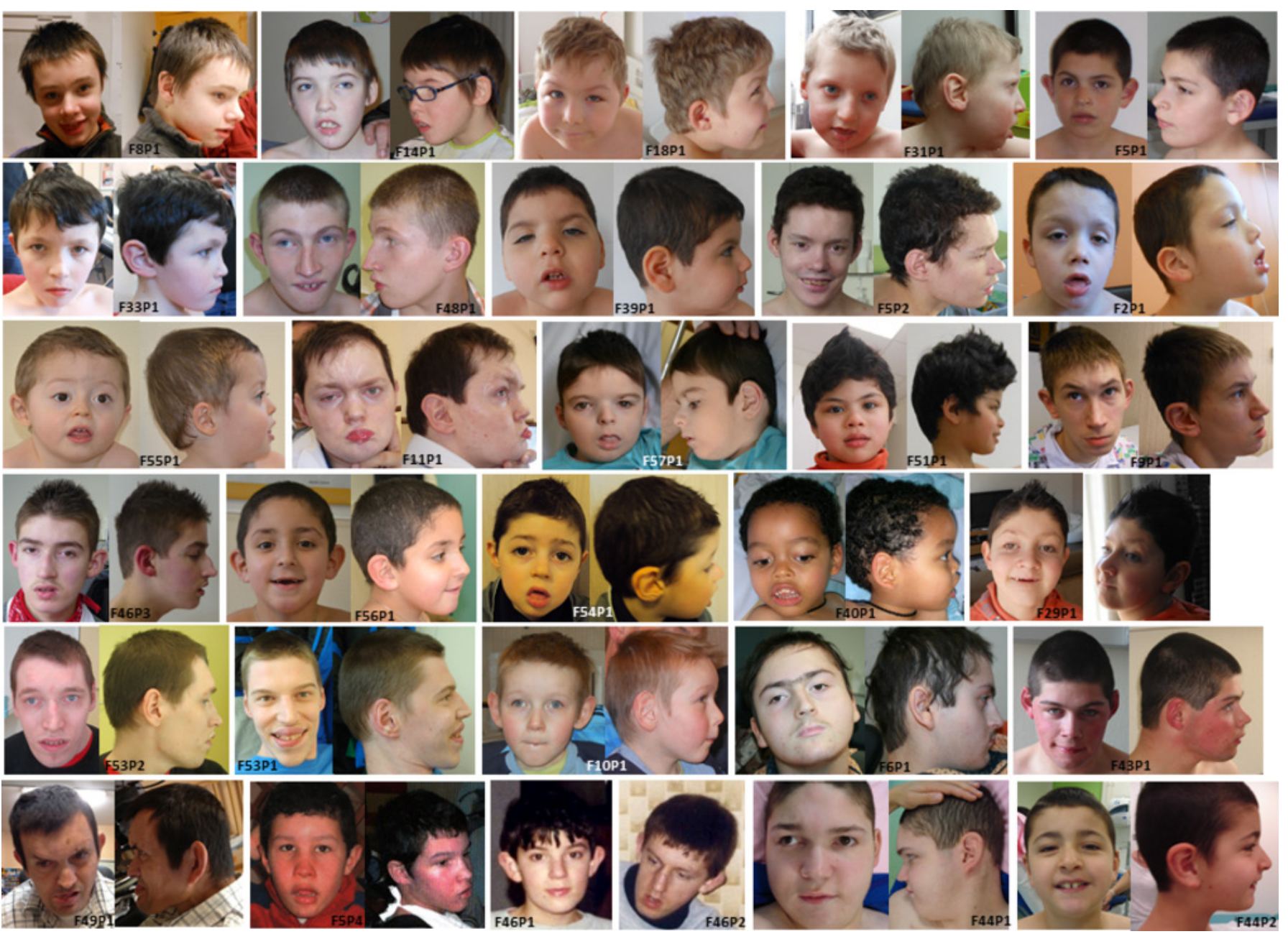

Figure 2 Facial phenotype of the patients with an interstitial Xq28 duplication involving MECP2. Patients share common facial features including an open mouth with a thick lower lip and intermittent drooling, large ears, midface hypoplasia, deep set eyes with frequent divergent strabismus, sparse eyebrows, narrow and prominent nasal bridge, dense and thick hair with an anterior sparse area.

In many patients, active epilepsy did not stop in late adolescence, since 12 of the 14 oldest living patients of our cohort (16-49 years), still experience seizures, including 10 who were drug-resistant. Among 31 patients for whom data were available, a neurological regression was observed after seizure onset in 12 patients (39\%), including 11 patients with drug-resistant
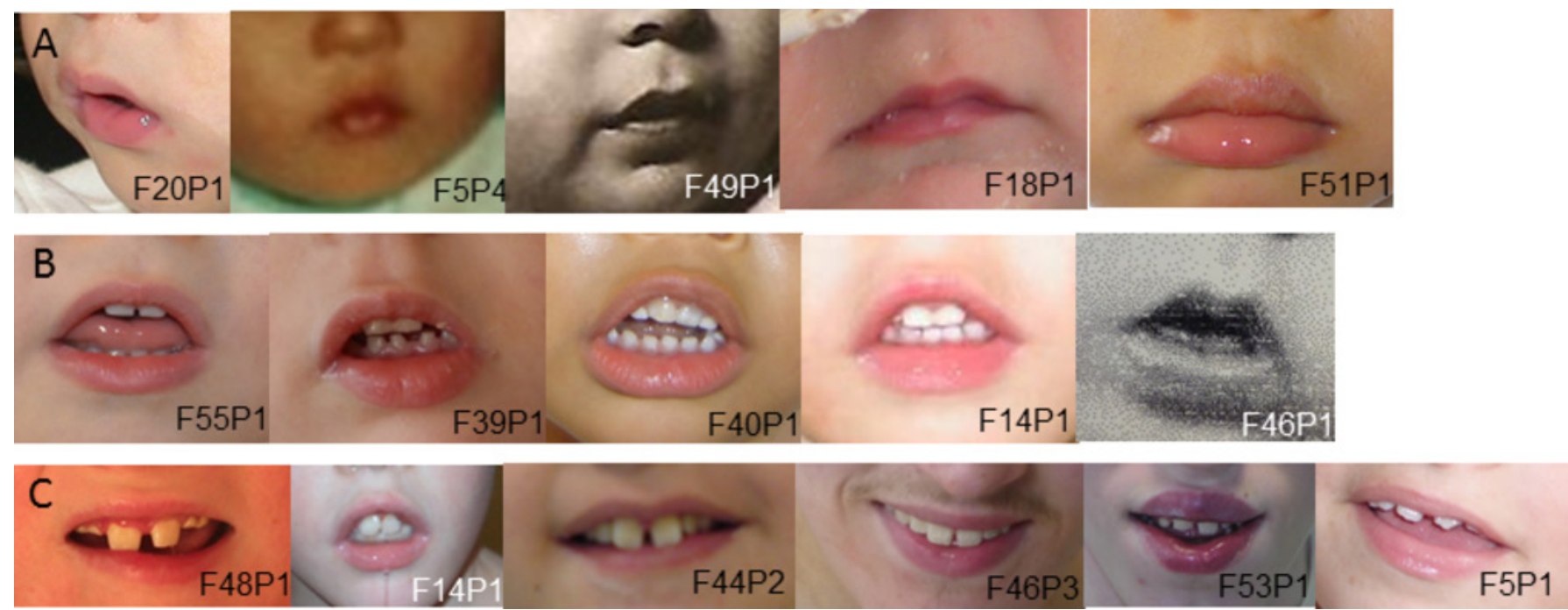

Figure 3 Focus on the lower part of the face in patients with an interstitial Xq28 duplication involving MECP2. Note the small mouth and the open mouth appearance with a convex upper lip during early infancy $(A, B)$, and the prominent central incisors after childhood (C). 

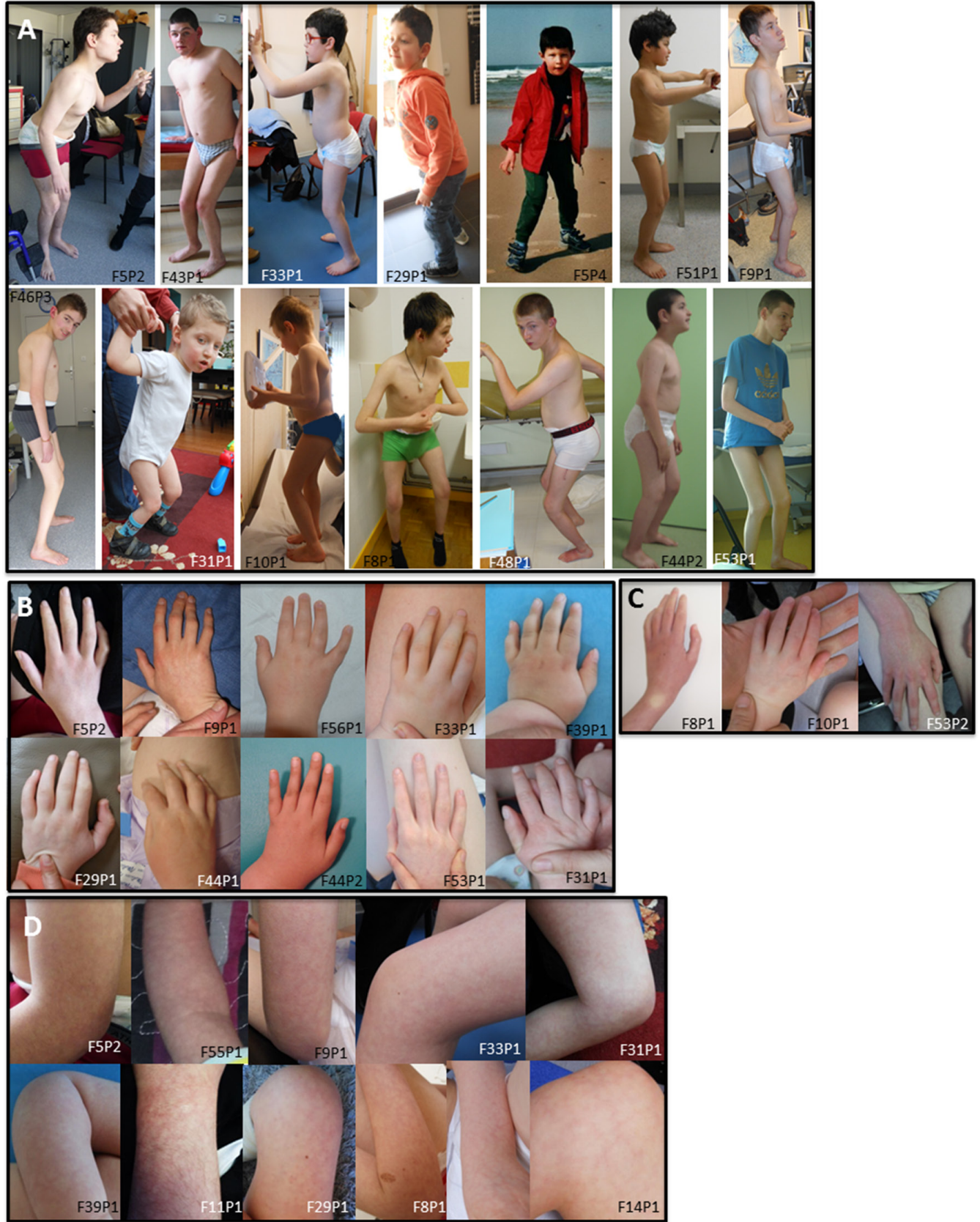

Figure 4 Common habitus with a flexion of the trunk and the knees (A), slender hands with tapering fingers and camptodactyly in few cases (F9P1, F44P1) (B), vasomotor troubles in the hands which appear red and wet (C), apparent venous network (livedo) of the limbs (D).

epilepsy. Among the $42 / 54$ (78\%) patients with the most severe developmental delay (5 youngest patients excluded), 14 (33\%) did not develop epilepsy.

\section{Communication and behaviour}

All of the patients had ID, which was severe in most of them. A majority of patients were dependent for daily life needs (dressing, bathing, toileting, etc). Only five children became toilet trained but two of them lost this skill. Among the patients for whom data were available, the majority did not develop speech $(32 / 57$, $56 \%)$ or had just babbling $(4 / 57,7 \%)$ or few words $(20 / 57$, $35 \%)$. However, we observed that for a few patients who had highly active familial and paramedical stimulations and re-education, a communicative strategy could be elaborated, including the use of pictograms. Many patients had stereotypies (49/55, $89 \%$ ), including flapping, midline hands movements, head movements and 33/46 (72\%) had bruxism. These stereotypic movements tended to appear during school age and persisted, in a variable way, throughout life. Regarding the autistic features, we could observe that, even though most of the patients had stereotypies and poor to absent language, with regression of skills for some, a considerable proportion demonstrated several interactions during the consultation, without social withdrawal, they smiled frequently and were interested in trying to carry out simple tasks.

In addition, a majority of parents reported to us decreased pain sensitivity $(29 / 37,78 \%$ ) (table 2$)$. The parents of two children who had broken their leg mentioned that they had not shown any pain.

\section{Other medical issues}

Not surprisingly, one of the most frequent features was chronic constipation, which was found in $78 \%$ of the 

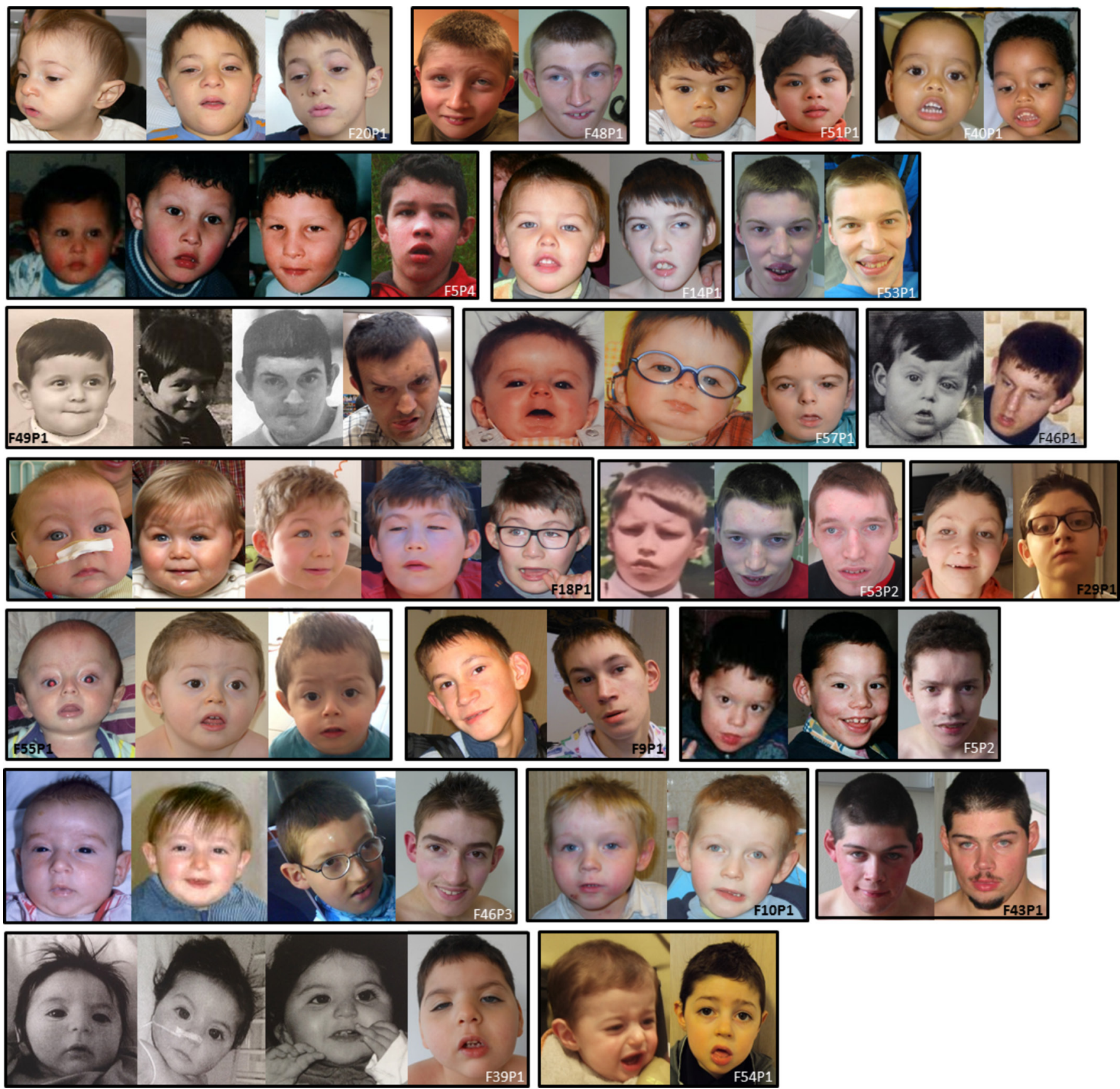

Figure 5 Evolution of the phenotype with time. Evolution of the facial features from early infancy to school age or adulthood (from left to right). Note the changing facial phenotype from round face with small mouth and nose to elongated coarser face with prominent nose and ears and thick lower lip.

patients (43/55), including in some of them, subobstruction episodes or even chronic intestinal pseudo-obstruction (CIPO) syndrome. When rectal biopsies were performed they were normal. Most of the patients had early feeding difficulties $(34 / 56,61 \%)$. They were partially due to an important gastro-oesophageal reflux $(34 / 51,67 \%)$ and to swallowing difficulties. These difficulties often disappeared with ageing and most of them were later described as having a very good appetite (table 2 ).

The majority of patients $(49 / 55,89 \%)$ had recurrent and severe respiratory infections requiring numerous hospitalisations, and recurrent ENT (pharyngitis, otitis, sinusitis) and urinary tract infections. These infections and their complications were the primary cause of premature death (table 2). We also noted significant obstructive sleep apnoea (16/49,
$33 \%)$, leading to adenoidectomy or tonsillectomy and sometimes to non-invasive mechanical ventilation.

Three patients (F41P2, F27P1, F27P3) suffered from pulmonary hypertension, which led to premature death, unrelated to a severe pulmonary infection, in two of them at the age of 11 months and 3 years, respectively. Another (F12P1), with right ventricular hypertrophy, died at the age of 19 years. One patient had been operated on for an atrial septum defect, one had a situs inversus and another had Bouveret tachycardia.

Urogenital anomalies were present in $43 \%$ of the patients (23/53) and included unilateral or bilateral cryptorchidism in $26 \%(14 / 53)$, micropenis in $9 \%(5 / 53)$, bilateral ureteral dilation in $9 \%(5 / 53)$ and bladder dilation or hypertrophy in three patients (table 2). 
Gynecomastia was observed in three patients.

\section{DISCUSSION}

Two large series of patients harbouring a MECP2 duplication have been reported to date, ${ }^{10}{ }^{12}$ including 129 and 56 affected patients, respectively. In addition, we previously reported the MRI data of 30 affected males and Bauer et al reported the immunological phenotype of 27 affected patients. ${ }^{27}$ Our present series describes the demographic and clinical features of 59 French male patients with a focus on the morphological and neurodevelopmental features in order to improve the phenotypical characterisation of this syndrome. However, given that this disorder can be easily diagnosed using Array-CGH, which is commonly requested in the diagnosis of ID, the results presented in this study will be of value for the follow-up of patients.

There was a wide age range, from 2 to 48 years, the latter being the oldest male patient diagnosed to date with MECP2 duplication syndrome to our knowledge, Friez et al having reported a man aged 46 years. ${ }^{28}$ Among the whole French series of 86 male patients with an intraC MECP2 duplication, $27 \%$ died before the age of 25 years (11 months to 24 years, mean age: 9.5 years), from respiratory infections for $73 \%$ of them-which is similar to what has already been reported ${ }^{1012}$ — pulmonary hypertension for $18 \%$ and epilepsy for $9 \%$. Like other authors, we were not able to demonstrate a clear correlation between the size of the duplication and the severity of the neurodevelopmental phenotype as the patients in our series with the smallest duplication did not have a milder neurological phenotype. ${ }^{15} 2229$

We observed that the large majority of the patients were born at term and with normal birth parameters (online supplementary table 2). Few fetal anomalies were noted during pregnancies, including brain malformations, intrauterine growth retardation in two cases and bilateral hydronephrosis in two cases. In the same way, Fu et al reported four fetuses harbouring a MECP2 duplication and indicated that ventriculomegaly, hydrocephalus, agenesis of the corpus callosum, choroid plexus cysts, fetal growth retardation and hydronephrosis might be recurrent obstetrical ultrasound findings in fetuses with this disorder. ${ }^{30}$ We observed obstetrical complications in $12.5 \%$ of pregnancies, including polyhydramnios $(7.8 \%)$, premature delivery threats $(5.9 \%)$ or toxaemia $(3.9 \%)$. Lim et al observed the same proportion of polyhydramnios and more hypertensive disorders $(19 \%) .^{12}$

We had previously described the OFC values in a smaller series of 30 patients and shown that there were nearly as many with microcephaly $(13 \%)$ as with macrocephaly $(17 \%) .{ }^{31}$ In the present series, we found that $7.5 \%$ of the patients were microcephalic and $17 \%$ were macrocephalic, which confirms that the OFC is not a key clinical feature in this syndrome (table 1). MECP2 duplication syndrome is classically described by a core phenotype that includes severe developmental delay with absent or very poor speech, epilepsy, respiratory infections and chronic constipation. ${ }^{79}$ Additionally, through a detailed analysis of the patients' phenotype during consultations and photographs taken at different ages, our study showed other similarities emerging between the patients affected by this condition including distinctive facial features and dental anomalies including shape and eruption anomalies (table 1, figures 2 and 3). However, these signs alone are not sufficient to raise the diagnosis of MECP2 duplication clinically. We studied the evolution of the facial features with ageing and noted that they became coarser and that the syndrome was more difficult to recognise in adulthood, as usual in syndromology. ${ }^{32}$
In the literature, these patients are frequently reported to be ataxic. ${ }^{710}$ We noted in the present study that they mainly had a flexion attitude of the knees with a broad-based stance, mainly due to both hypotonia and spasticity, which led to a peculiar and unsteady gait (figure 4A). Another particularity was a decreased sensitivity to pain (29/37), which was also reported by Lim et al in $50 \%$ of their series. ${ }^{12}$

We also noticed frequent vasomotor problems, and a livedo of the limbs. Some of these signs had already been reported individually, like in the patient reported by Clayton-Smith et al who was described with a thin appearing skin and cold red feet with poor circulation. ${ }^{7}$ The association of decreased sensitivity to pain, chronic constipation, vasomotor troubles and unsteady gait with an abnormal posture could possibly result from an abnormal development of the proprioceptive and nociceptive pathways. Most of the patients developed kyphoscoliosis, which is important to take into account in their clinical care in order to start physiotherapy early in life and prescribe an orthopaedic corset when necessary. It seems important to note that some of these clinical features, including vasomotor troubles, small cold hands and feet, decreased response to pain, the stereotypic movements, bruxism and gait abnormalities are also supportive criteria of Rett syndrome. However, in MECP2 duplication syndrome, the development is abnormal from the outset and we do not observe frequently a deceleration of the OFC or breathing disturbances when awake. ${ }^{33}$

In our series, among the $32 / 59$ patients with epilepsy, $62 \%$ were drug-resistant, compared with $76 \%$ in the series of Lim et al. ${ }^{12}$ Multiple different seizure types (table 2) and different EEG patterns (data not shown) were observed, which is consistent with other reports. ${ }^{24335}$ Peters et al previously described that among 17 males with MECP2 duplication syndrome, 7 (41\%) exhibited regression in motor skills, which coincided with seizure onset in 6 of them, compared with 12/31 (39\%) patients in the present series. ${ }^{36}$ We observed very frequent bruxism and hand stereotypies as did other authors. ${ }^{12}{ }^{24}{ }^{29}$ Compared with typical Rett syndrome, in which the onset of stereotypies mostly precedes or coincides with the loss of purposeful hand movements between ages 1 and 4 years (stage II) and tends to decrease after age 10 years, ${ }^{37}{ }^{38}$ stereotypies in MECP2 duplication patients tend to appear during school age and will persist, in a variable way, throughout life.

Although some MECP2 duplication patients have been reported as having autistic behaviour, ${ }^{829}$ we observed that most of them had good social interactions, although we could not confirm this clinical impression with standardised diagnostic tool since our series was partly retrospective. In the same way, Xi et al did not find any MECP2 duplication in a series of 82 autistics males, suggesting that this disorder is not frequent in patients with autism. ${ }^{39}$ Conversely, hearing loss is not often reported in the literature in MECP2 duplication patients. Since we found hearing impairment in $7 / 23$ patients in our cohort, this sensory impairment must be systematically assessed to avoid worsening of communication skills.

Digestive problems, ranging from chronic constipation to CIPO, are well-known features in MECP2 duplication patients. Lim et al noted that chronic constipation was present in $80 \%$ of the subjects in their series. ${ }^{12}$ This is consistent with our findings $(78 \%)$, but seems to be more frequent than in previous reports (table 3$).{ }^{10}{ }^{11}$ Several hypotheses were raised on the origin of the chronic constipation. Clayton-Smith et al attributed this to the FLNA gene, often involved in the duplication, and supported by the fact that point mutations in this gene were found in $\mathrm{X}$ linked families with pseudo-obstruction. ${ }^{7041}$ Fernandes et al, on the 
Table 3 Comparison of the clinical data from the present study and those reported by Van Esch et al and Lim et al ${ }^{10-12}$

\begin{tabular}{|c|c|c|c|}
\hline & $\begin{array}{l}\text { Van Esch } \\
\text { et al (\%) }\end{array}$ & $\begin{array}{l}\text { Lim et al } \\
(\%)\end{array}$ & $\begin{array}{l}\text { Present } \\
\text { study (\%) }\end{array}$ \\
\hline Patient number & 129 & 49 & 59 \\
\hline Gender & M & $M$ & $M$ \\
\hline Age at diagnosis (years) & NR & 3 & 10 \\
\hline Age at examination (years) & NR & 7.9 & 12 \\
\hline Neonatal complications & NR & $33^{*}$ & $32 / 58(55)$ \\
\hline Early death (<25 years) & $34 / 88(39)$ & NR & 9/59 (15) \\
\hline Facial dysmorphism & $65 / 86(76)$ & NR & $51 / 55(93)$ \\
\hline \multicolumn{4}{|l|}{ Growth } \\
\hline Head circumference (SDS) & Normal range & NR & 0.2 \\
\hline Height (SDS) & Normal range & NR & -0.4 \\
\hline Weight (SDS) & Normal range & NR & 0.4 \\
\hline \multicolumn{4}{|l|}{ Neurodevelopment } \\
\hline Developmental delay & $129 / 129(100)$ & $41 / 49(84)$ & $59 / 59(100)$ \\
\hline Early hypotonia & 110/117 (94) & $31 / 48(65)$ & $57 / 58(98)$ \\
\hline Seizures & $66 / 123(54)$ & $21 / 49(43)$ & $35 / 59$ (59) \\
\hline Drug resistance & NR & $17 / 21(81)$ & $21 / 34(62)$ \\
\hline Age at onset of seizures (years) & 6 & 1 to 20 & 7.4 \\
\hline Type of seizures & $\mathrm{TC}, \mathrm{At}, \mathrm{Ab}, \mathrm{M}$ & NR & $\begin{array}{l}\text { TC, At, Ab, } \\
M, C P\end{array}$ \\
\hline Walking age (years) & $\begin{array}{l}18 \text { months to } 4 \\
\text { years }\end{array}$ & 4 & 3.6 \\
\hline Walking without support & $83 / 109(76)$ & $13 / 49(27)$ & $37 / 56(66)$ \\
\hline Absent speech & $86 / 109(79)$ & $23 / 46(50)$ & $32 / 57(56)$ \\
\hline Stereotyped movements & $20 / 78(26)$ & $\begin{array}{l}55 \% \text { at } \\
3 \text { years }\end{array}$ & 49/55 (89) \\
\hline \multicolumn{4}{|l|}{ Gastrointestinal anomalies } \\
\hline Chronic constipation & 29/88 (33) & $37 / 45(82)$ & $43 / 55(78)$ \\
\hline Gastrooesophageal reflux & NR & $26 / 49(53)$ & $34 / 51(67)$ \\
\hline Recurrent pulmonary infections & $87 / 121(72)$ & $38 / 49(78)$ & 49/55 (89) \\
\hline \multicolumn{4}{|l|}{ Skeletal anomalies } \\
\hline $\begin{array}{l}\text { Flexion of the knees and the } \\
\text { trunk }\end{array}$ & $57 / 89(64)$ & NR & $42 / 49(86)$ \\
\hline Scoliosis and/or kyphosis & NR & $10 / 46(22)$ & $23 / 43(53)$ \\
\hline Decreased pain sensitivity & NR & $25 / 50^{*}(50)$ & 29/37 (78) \\
\hline
\end{tabular}

*Includes both males and females.

$A t$, atonic; $\mathrm{M}$, myoclonic; $\mathrm{Ab}$, absence; $\mathrm{CP}$, complex partial; $\mathrm{TC}$, tonic-clonic; NR, not reported; SDS, SD score.

other hand, hypothesised that this feature may be linked to the duplication of L1CAM, which is expressed in the enteric nervous system, plays a key role in its development during embryogenesis and has been found to be mutated in some patients with either X linked hydrocephalus or acrocallosal syndrome and Hirschsprung disease. ${ }^{42-44}$ In our series, among 39 patients with chronic constipation and for whom molecular data were available, we found that the duplication included FLNA and L1CAM in 25 cases, only L1CAM or only FLNA in 9 and 4 cases respectively, and none of them in 1 case. Therefore, in addition to the frequent constipation rate described in patients with severe neurological handicap, we may speculate whether increased dosage of both FLNA and L1CAM genes could be responsible for the increased risk to develop a severe constipation in these patients.

Recurrent and severe infections were a significant health issue for $89 \%$ of MECP2 duplication patients, as in the study by Lim et $a l$, who found recurrent respiratory infections in $78 \%$ of affected males, three-quarters of them requiring hospital admissions within the first 2 years of life for supportive care and interventional procedures (mechanical ventilation, intravenous antibiotics, tracheostomy). ${ }^{12}$ Van Esch, in a review of 129 affected males, reported $70 \%$ of recurrent infections, especially of the respiratory tract. ${ }^{10}$ These results raise again the question of the use of a long-term prophylactic antibiotic therapy in these males. It has been shown that increased susceptibility to infections in MECP2 duplication syndrome is associated with defects in the interferon- $\gamma$-mediated TH1 response, ${ }^{45}$ IgA/IgG2 deficiency, low antibody titres against pneumococci and elevated acute-phase responses. Some authors suggest prophylactic IgG substitution in MECP2 duplication patients with low $\operatorname{IgA} / \operatorname{IgG} 2$ rates. $^{27}$

Three patients in our series suffered from pulmonary hypertension $(\mathrm{PH})$, being lethal for two of them. Two other unrelated MECP2 duplication patients who had lethal pulmonary hypertension, have been reported (rarechromosome.org-Xq28 duplication; http://www.goldcoastbulletin.com.au/news/gold-coast/ gold-coast-family-mourns-11monthold-after-mystery-heart-attack/ news-story/4d1f28630e5b6780359721cad0e41988). Interestingly, Cronk et al showed that Influenza A infected $\mathrm{MeCP}_{2}{ }^{\mathrm{Tg} 3}$ mice, overexpressing $\mathrm{MeCP} 2$ at levels threefold to fivefold higher than normal, experienced $\mathrm{PH}$ and arterial narrowing, which contributed to infection-related mortality. ${ }^{46}$ In our series, we speculate that $\mathrm{PH}$ might be the cause of the sudden and unexplained death of some patients, especially as MECP2 duplication patients do not usually undergo regular cardiac evaluation. We believe that these findings are important enough to introduce a cardiac assessment in these patients from the first year of life and then regularly, especially in patients who experienced several pulmonary infections.

Urogenital anomalies, in particular cryptorchidism and micropenis, were more frequent (26\%) than in the literature, ${ }^{823444748}$ and gynecomastia was present in three patients, suggesting the possible existence of hypogonadism in this syndrome.

In conclusion, we report on the clinical and morphological features of 59 affected males with interstitial MECP2 duplication in order to expand the clinical phenotype of MECP2 duplication syndrome. Most of the clinical findings were consistent with previous data and we demonstrated that these patients shared common facial features that tend to evolve with age. In addition, we described commonly associated morphological and neuro-orthopaedic features not reported to date, such as a trunk and knees-flexion habitus leading to an ataxic-like gait. Pulmonary hypertension appeared as a cause of early death in these patients, which suggests that patients may benefit from regular cardiac assessment.

\section{URLS}

USCS, https://genome.ucsc.edu/

\section{Author affiliations}

'Service de génétique médicale, Institut de Génétique Médicale d'Alsace (IGMA), Centre de Référence Maladies Rares "Anomalies du développement et syndromes malformatifs", Centre de Référence Maladies Rares "Des déficiences intellectuelles de causes rares", Hôpitaux Universitaires de Strasbourg, Hôpital de Hautepierre, Strasbourg, France

${ }^{2}$ FHU TRANSLAD, Centre de Référence Maladies Rares «Anomalies du développement et syndromes malformatifs», Centre de Génétique, CHU de Dijon, Dijon, France

${ }^{3}$ Service de Génétique Clinique, Hôpital Necker Enfants Malades, APHP, Paris, France ${ }^{4}$ Service de Génétique Clinique, CHU de Saint-Etienne, Saint-Etienne, France ${ }^{5}$ Service de Génétique Clinique, CLAD Ouest, CHU de Rennes, Rennes, France ${ }^{6}$ Laboratoire de Génétique Moléculaire, CHU de Rennes, Rennes, France

${ }^{7}$ Service de Génétique Médicale, CHU de Toulouse, Toulouse, France

${ }^{8}$ Service de Neuropédiatrie, CHU de Clermont-Ferrand, Clermont-Ferrand, France

${ }^{9}$ Service de Génétique Médicale, CHU de Clermont-Ferrand, Clermont-Ferrand, France

${ }^{10}$ Service de Neuropédiatrie et Maladies Métaboliques, Hôpital Robert Debré, APHP,

Paris, France

${ }^{11}$ Service de Génétique Médicale, CHU de Nantes, Nantes, France 
${ }^{12}$ Service de Génétique Médicale, CHU de Nancy, Nancy, France

${ }^{13}$ Laboratoire de Génétique Médicale, CHU de Nancy, Nancy, France

${ }^{14}$ Service de Neuropédiatrie, CHRU de Lille, Lille, France

${ }^{15}$ Laboratoire de Génétique Médicale, Hôpital Jeanne de Flandre, CHRU de Lille, Lille, France

${ }^{16}$ Service de Génétique, CHU de Caen, Caen, France

${ }^{17}$ Service de Génétique, CHRU de Tours, Tours, France

${ }^{18}$ Service de Radiologie, Hôpital Femme Mère Enfant, Bron, France

${ }^{19}$ Laboratoire de Biologie Moléculaire, Hôpital Necker Enfants Malades, APHP, Paris, France

${ }^{20}$ Service de Neurologie pédiatrique, CHU de Montpellier, Montpellier, France

${ }^{21}$ Service de Génétique, Centre Hospitalier de Vannes, Vannes, France

${ }^{22}$ Service de Génétique, Hôpital Armand Trousseau, APHP, Paris, France

${ }^{23}$ Laboratoire de Génétique Moléculaire, GH Cochin-Broca Hôtel Dieu, APHP, Paris, France

${ }^{24}$ Service de Génétique Clinique, Hôpital Robert Debré, APHP, Paris, France

${ }^{25}$ Laboratoire de Biologie Moléculaire, Hôpital Robert Debré, APHP, Paris, France

${ }^{26}$ Département de Génétique et Procréation - UMR CNRS 5525 TIMC-IMAG - équipe

DYCTIM, CHU Grenoble, Grenoble, France

${ }^{27}$ Université de Bordeaux, Laboratoire MRGM, INSERM U1211 and Service de Génétique Médicale, CHU de Bordeaux, Bordeaux, France

${ }^{28}$ Département de Génétique Médicale, Hôpital de la Timone, Marseille, France

${ }^{29}$ Laboratoire de Génétique Chromosomique, Hôpital de la Timone, Marseille, France

${ }^{30}$ Laboratoire de Biologie Moléculaire, Hôpital de la Timone, Marseille, France

${ }^{31} \mathrm{CIC} 1407$ Inserm, CHU de Lyon, Lyon, France

${ }^{32}$ Réseau d'Analyse Chromosomique sur Puces à ADN (AChro-Puce)

${ }^{33}$ Unité de Neuropédiatrie, CHU Pellegrin, Bordeaux, France

${ }^{34}$ Clinique de Génétique Guy Fontaine, CHRU de Lille, Hôpital Jeanne de Flandre, Lille, France

${ }^{35}$ Centre de Génétique Chromosomique, GH de I'Institut Catholique de Lille, Hôpital Saint-Vincent-de-Paul, Lille, France

${ }^{36}$ Service de Neuropédiatrie, Hôpital Necker Enfants Malades, APHP, Paris, France

${ }^{37}$ Département de Génétique Médicale, Centre de Référence "Malformations et maladies congénitales du cervelet", APHP, Hôpital Armand Trousseau, APHP, Paris, France

${ }^{38}$ Service de Génétique Clinique, Hôpital Pitié-Salpêtrière, APHP, Paris, France

${ }^{39}$ Service de Pédiatrie, CHU Félix Guyon, Saint-Denis, France

${ }^{40}$ UF génétique médicale, Centre Hospitalier du Mans, Le Mans, France

${ }^{41}$ Service de génétique, Hospices Civils de Lyon, Lyon, France

${ }^{42}$ INSERM U1028, CNRS UMR5292, Centre de Recherche en Neurosciences de Lyon, GENDEV Team, Université Claude Bernard Lyon 1, Lyon, France

${ }^{43}$ Laboratoire de Génétique Moléculaire, CHRU de Tours, Tours, France

${ }^{44}$ Laboratoire de Cytogénétique, CHU de Dijon, Dijon, France

${ }^{45}$ Laboratoire de Cytogénétique, CHU de Grenoble, Grenoble, France

${ }^{46}$ Laboratoire de Cytogénétique, CHU de Nantes, Nantes, France

${ }^{47}$ Sarcomes osseux et remodelage des tissus calcifiés, Université Bretagne Loire, INSERM, UMR1238, Nantes, France

${ }^{48}$ Laboratoire de Cytogénétique, Hôpital Necker Enfants Malades, APHP, Paris, France

${ }^{49}$ Laboratoire de Cytogénétique, Hôpital Pitié-Salpêtrière, APHP, Paris, France

${ }^{50}$ Laboratoire de Cytogénétique, Hôpital Robert Debré, APHP, Paris, France

${ }^{51}$ Laboratoire de Cytogénétique, CHU de Strasbourg, Hôpital de Hautepierre,

Strasbourg, France

${ }^{52}$ Laboratoire de Cytogénétique, CHU de Toulouse, Toulouse, France

${ }^{53}$ Service de Génétique Médicale, CHU de Pointe à Pitre, Pointe à Pitre, France

${ }^{54}$ Laboratoire de Cytogénétique, CHU de Lyon, Lyon, France

${ }^{55}$ Service de Neuropédiatrie, CHU de Lyon, Hôpital Femme-Mère-Enfant, Lyon, France

${ }^{56}$ Service de Génétique Médicale, CHU de Poitiers, Poitiers, France

${ }^{57}$ Service de Génétique Médicale, CHU de Montpellier, Montpellier, France

${ }^{58}$ Laboratory for Genetics of Cognition, Center for Human Genetics, University Hospitals Leuven, Leuven, Belgium

${ }^{59}$ Centre de Référence Maladies Rares «Des déficiences intellectuelles de causes

rares», HFME, Hospices Civils de Lyon and Université de Lyon, Lyon, France

${ }^{60}$ Institut des Sciences Cognitives, CNRS UMR 5304, Bron, France

Acknowledgements The authors are deeply grateful to the patients and their parents for their participation in this study. The authors would like to thank the association Xtraordinaire for their financial support of the project, and the French Ministry of Health (PHRC RMLX 2008, Pr V. Des Portes) for its support. The authors would like to thank the AChro-Puce network for its help in collecting cytogenetic data. The authors would also like to thank Mr James Garfield for his helpful review of this article.

Contributors MM wrote the paper, MN, CD, CP, JA, JPB, SCB, TB, MT, SDS, SD, AM, CB, CRT, GL, MR, CM, JT, MBD, DS, PC, ALM, NM, CC, VS, VM, SR, BK, ACT, VK, SS, AV and RAP analysed the cytogenetic and molecular data. LF, JA, RT, FP, LP, ML, SJ, CS, $C F, F L, O B T, A D, B I, J V, B L, L L, J M C, G P, A T, A G, V C D, M R, B E, G R, H J, L B, C B, L P, P S J$ $K D, F D, D L, N P, S S, C T R, J M P, C G, C V D, B D B, N B B, A A, K M, C L C, D H$, JLA, GL, MLPL, $M R, B G D, M W, M C, H V E$ and $D M C$ are the referring clinicians. LG interpreted brain
MRI of many patients of the cohort, VD and NP respectively directed and organised the PHRC RMLX, SEC collected the clinical and molecular data and the photographs during consultations (for 25 patients) or by contacting the clinicians and the labs, and supervised this work

Funding The authors have not declared a specific grant for this research from any funding agency in the public, commercial or not-for-profit sectors.

Competing interests None declared.

Patient consent Detail has been removed from this case description/these case descriptions to ensure anonymity. The editors and reviewers have seen the detailed information available and are satisfied that the information backs up the case the authors are making.

Ethics approval The ethics committee "Comité de Protection des Personnes SUD-EST II" delivered a favourable opinion (22 September 2010) with regard to the realisation of the XLID Research Project 2008-2016 (RMLX).

Provenance and peer review Not commissioned; externally peer reviewed.

(c) Article author(s) (or their employer(s) unless otherwise stated in the text of the article) 2018. All rights reserved. No commercial use is permitted unless otherwise expressly granted.

\section{REFERENCES}

1 Adkins NL, Georgel PT. MeCP2: structure and function. Biochem Cell Biol 2011:89:1-11.

2 Chahrour M, Jung SY, Shaw C, Zhou X, Wong ST, Qin J, Zoghbi HY. MeCP2, a key contributor to neurological disease, activates and represses transcription. Science 2008;320:1224-9.

3 Gonzales ML, LaSalle JM. The role of MeCP2 in brain development and neurodevelopmental disorders. Curr Psychiatry Rep 2010;12:127-34.

4 Amir RE, Van den Veyver IB, Wan M, Tran CQ, Francke U, Zoghbi HY. Rett syndrome is caused by mutations in X-linked MECP2, encoding methyl-CpG-binding protein 2. Nat Genet 1999:23:185-8.

5 Villard L. MECP2 mutations in males. J Med Genet 2007:44:417-23.

6 Lambert S, Maystadt I, Boulanger S, Vrielynck P, Destrée A, Lederer D, Moortgat S. Expanding phenotype of p.Ala140Val mutation in MECP2 in a 4 generation family with X-linked intellectual disability and spasticity. Eur J Med Genet 2016;59:522-5.

7 Clayton-Smith J, Walters S, Hobson E, Burkitt-Wright E, Smith R, Toutain A, Amiel J, Lyonnet S, Mansour S, Fitzpatrick D, Ciccone R, Ricca I, Zuffardi O, Donnai D. Xq28 duplication presenting with intestinal and bladder dysfunction and a distinctive facial appearance. Eur J Hum Genet 2009;17:434-43.

8 del Gaudio D, Fang P, Scaglia F, Ward PA, Craigen WJ, Glaze DG, Neul JL, Patel A, Lee JA, Irons M, Berry SA, Pursley AA, Grebe TA, Freedenberg D, Martin RA, Hsich GE, Khera JR, Friedman NR, Zoghbi HY, Eng CM, Lupski JR, Beaudet AL, Cheung SW, Roa BB. Increased MECP2 gene copy number as the result of genomic duplication in neurodevelopmentally delayed males. Genet Med 2006:8:784-92.

9 van Esch H, Bauters M, Ignatius J, Jansen M, Raynaud M, Hollanders K, Lugtenberg D, Bienvenu T, Jensen LR, Gecz J, Moraine C, Marynen P, Fryns JP, Froyen G. Duplication of the MECP2 region is a frequent cause of severe mental retardation and progressive neurological symptoms in males. Am J Hum Genet 2005;77:442-53.

10 van Esch H. MECP2 Duplication Syndrome. Mol Syndromol 2012:2:128-36.

11 van Esch H. MECP2 Duplication Syndrome. GeneReviews(R). Seattle (WA): University of Washington, Seattle, 1993.

12 Lim Z, Downs J, Wong K, Ellaway C, Leonard H. Expanding the clinical picture of the MECP2 Duplication syndrome. Clin Genet 2017:91:557-63.

13 Grasshoff U, Bonin M, Goehring I, Ekici A, Dufke A, Cremer K, Wagner N, Rossier E, Jauch A, Walter M, Bauer C, Bauer P, Horber K, Beck-Woedl S, Wieczorek D. De novo MECP2 duplication in two females with random $X$-inactivation and moderate mental retardation. Eur J Hum Genet 2011;19:507-12.

14 Bijlsma EK, Collins A, Papa FT, Tejada MI, Wheeler P, Peeters EA, Gijsbers AC, van de Kamp JM, Kriek M, Losekoot M, Broekma AJ, Crolla JA, Pollazzon M, Mucciolo M, Katzaki E, Disciglio V, Ferreri MI, Marozza A, Mencarelli MA, Castagnini C, Dosa L, Ariani F, Mari F, Canitano R, Hayek G, Botella MP, Gener B, Mínguez M, Renieri A, Ruivenkamp CA. Xq28 duplications including MECP2 in five females: Expanding the phenotype to severe mental retardation. Eur J Med Genet 2012;55(6-7):404-13.

15 Shimada S, Okamoto N, Ito M, Arai Y, Momosaki K, Togawa M, Maegaki Y, Sugawara M, Shimojima K, Osawa M, Yamamoto T. MECP2 duplication syndrome in both genders. Brain Dev 2013;35:411-9

16 Scott Schwoerer J, Laffin J, Haun J, Raca G, Friez MJ, Giampietro PF. MECP2 duplication: possible cause of severe phenotype in females. Am J Med Genet $A$ 2014:164A:1029-34

17 El Chehadeh S, Touraine R, Prieur F, Reardon W, Bienvenu T, Chantot-Bastaraud S, Doco-Fenzy M, Landais E, Philippe C, Marle N, Callier P, Mosca-Boidron AL, Mugneret F, Le Meur N, Goldenberg A, Guerrot AM, Chambon P, Satre V, Coutton C, Jouk PS, Devillard F, Dieterich K, Afenjar A, Burglen L, Moutard ML, Addor MC, Lebon S, Martinet D, Alessandri JL, Doray B, Miguet M, Devys D, Saugier-Veber P, Drunat S, Aral B, Kremer V, Rondeau S, Tabet AC, Thevenon J, Thauvin-Robinet C, Perreton N, 
Portes D V, Faivre L. Xq28 duplication including MECP2 in six unreported affected females: what can we learn for diagnosis and genetic counselling? Clin Genet 2017:91:576-88.

18 Collins AL, Levenson JM, Vilaythong AP, Richman R, Armstrong DL, Noebels JL, David Sweatt J, Zoghbi HY. Mild overexpression of MeCP2 causes a progressive neurological disorder in mice. Hum Mol Genet 2004;13:2679-89.

19 Chao HT, Zoghbi HY, Rosenmund C. MeCP2 controls excitatory synaptic strength by regulating glutamatergic synapse number. Neuron 2007:56:58-65.

20 Nageshappa S, Carromeu C, Trujillo CA, Mesci P, Espuny-Camacho I, Pasciuto E, Vanderhaeghen P, Verfaillie CM, Raitano S, Kumar A, Carvalho CM, Bagni C, Ramocki MB, Araujo BH, Torres LB, Lupski JR, van Esch H, Muotri AR. Altered neuronal network and rescue in a human MECP2 duplication model. Mol Psychiatry 2016;21:178-88.

21 Sztainberg Y, Chen HM, Swann JW, Hao S, Tang B, Wu Z, Tang J, Wan YW, Liu Z, Rigo F, Zoghbi HY. Reversal of phenotypes in MECP2 duplication mice using genetic rescue or antisense oligonucleotides. Nature 2015;528:123-6.

22 Bauters M, van Esch H, Friez MJ, Boespflug-Tanguy O, Zenker M, Vianna-Morgante AM, Rosenberg C, Ignatius J, Raynaud M, Hollanders K, Govaerts K, Vandenreijt K, Niel F, Blanc P, Stevenson RE, Fryns JP, Marynen P, Schwartz CE, Froyen G. Nonrecurrent MECP2 duplications mediated by genomic architecture-driven DNA breaks and break-induced replication repair. Genome Res 2008;18:847-58.

23 Lugtenberg D, Kleefstra T, Oudakker AR, Nillesen WM, Yntema HG, Tzschach A Raynaud M, Rating D, Journel H, Chelly J, Goizet C, Lacombe D, Pedespan JM, Echenne B, Tariverdian G, O'Rourke D, King MD, Green A, van Kogelenberg M, van Esch H, Gecz J, Hamel BC, van Bokhoven H, de Brouwer AP. Structural variation in Xq28: MECP2 duplications in $1 \%$ of patients with unexplained XLMR and in $2 \%$ of male patients with severe encephalopathy. Eur J Hum Genet 2009;17:444-53.

24 Ramocki MB, Tavyev YJ, Peters SU. The MECP2 duplication syndrome. Am J Med Genet A 2010;152A:1079-88.

25 Association AP. Diagnostic and statistical manual of mental disorders: DSM-5. 5th ed. United States: Washington, D.C: ed American Psychiatric Association, 2013.

26 Schouten JP, McElgunn CJ, Waaijer R, Zwijnenburg D, Diepvens F, Pals G. Relative quantification of 40 nucleic acid sequences by multiplex ligation-dependent probe amplification. Nucleic Acids Res 2002;30:57e-57.

27 Bauer M, Kölsch U, Krüger R, Unterwalder N, Hameister K, Kaiser FM, Vignoli A, Rossi R, Botella MP, Budisteanu M, Rosello M, Orellana C, Tejada MI, Papuc SM, Patat O, Julia S, Touraine R, Gomes T, Wenner K, Xu X, Afenjar A, Toutain A, Philip N, Jezela-Stanek A, Gortner L, Martinez F, Echenne B, Wahn V, Meisel C, Wieczorek D, El-Chehadeh S, Van Esch H, von Bernuth H. Infectious and immunologic phenotype of MECP2 duplication syndrome. J Clin Immunol 2015:35:168-81.

28 Friez MJ, Jones JR, Clarkson K, Lubs H, Abuelo D, Bier JA, Pai S, Simensen R, Williams C, Giampietro PF, Schwartz CE, Stevenson RE. Recurrent infections, hypotonia, and mental retardation caused by duplication of MECP2 and adjacent region in Xq28. Pediatrics 2006;118:e1687-e1695.

29 Ramocki MB, Peters SU, Tavyev YJ, Zhang F, Carvalho CM, Schaaf CP, Richman R, Fang P, Glaze DG, Lupski JR, Zoghbi HY. Autism and other neuropsychiatric symptoms are prevalent in individuals with MeCP2 duplication syndrome. Ann Neurol 2009;66:771-82.

30 Fu F, Liu HL, Li R, Han J, Yang X, Min P, Zhen L, Zhang YL, Xie GE, Lei TY, Li Y, Li J, Li DZ, Liao C. Prenatal diagnosis of foetuses with congenital abnormalities and duplication of the MECP2 region. Gene 2014;546:222-5.

31 El Chehadeh S, Faivre L, Mosca-Boidron AL, Malan V, Amiel J, Nizon M, Touraine R, Prieur F, Pasquier L, Callier P, Lefebvre M, Marle N, Dubourg C, Julia S, Sarret C, Francannet $C$, Laffargue F, Boespflug-Tanguy 0 , David A, Isidor B, Le Caignec C, Vigneron J, Leheup B, Lambert L, Philippe C, Cuisset JM, Andrieux J, Plessis G, Toutain A, Goldenberg A, Cormier-Daire V, Rio M, Bonnefont JP, Thevenon J, Echenne B, Journel H, Afenjar A, Burglen L, Bienvenu T, Addor MC, Lebon S, Martinet D, Baumann C, Perrin L, Drunat S, Jouk PS, Devillard F, Coutton C, Lacombe D, Delrue MA, Philip N, Moncla A, Badens C, Perreton N, Masurel A, Thauvin-Robinet C, Des Portes V,
Guibaud L. Large national series of patients with Xq28 duplication involving MECP2: Delineation of brain MRI abnormalities in 30 affected patients. Am J Med Genet $A$ 2016;170A:116-29.

32 Van Buggenhout GJ, Pijkels E, Holvoet M, Schaap C, Hamel BC, Fryns JP. Cri du chat syndrome: changing phenotype in older patients. Am J Med Genet 2000;90:203-15.

33 Christodoulou J, Ho G. MECP2-Related Disorders. GeneReviews((R)). Seattle (WA: University of Washington, Seattle, 1993.

34 Vignoli A, Borgatti R, Peron A, Zucca C, Ballarati L, Bonaglia C, Bellini M, Giordano L, Romaniello R, Bedeschi MF, Epifanio R, Russo S, Caselli R, Giardino D, Darra F, La Briola F, Banderali G, Canevini MP. Electroclinical pattern in MECP2 duplication syndrome: eight new reported cases and review of literature. Epilepsia 2012;53:1146-55.

35 Echenne B, Roubertie A, Lugtenberg D, Kleefstra T, Hamel BC, Van Bokhoven H, Lacombe D, Philippe C, Jonveaux P, de Brouwer AP. Neurologic aspects of MECP2 gene duplication in male patients. Pediatr Neurol 2009;41:187-91.

36 Peters SU, Hundley RJ, Wilson AK, Carvalho CM, Lupski JR, Ramocki MB. Brief report: regression timing and associated features in MECP2 duplication syndrome. J Autism Dev Disord 2013;43:2484-90.

37 Temudo T, Oliveira P, Santos M, Dias K, Vieira J, Moreira A, Calado E, Carrilho I, Oliveira G, Levy A, Barbot C, Fonseca M, Cabral A, Dias A, Cabral P, Monteiro J, Borges L, Gomes R, Barbosa C, Mira G, Eusébio F, Santos M, Sequeiros J, Maciel P. Stereotypies in Rett syndrome: analysis of 83 patients with and without detected MECP2 mutations. Neurology 2007;68:1183-7.

38 Chin Wong L, Hung PL, Jan TY, Lee WT; Taiwan Rett Syndrome Association. Variations of stereotypies in individuals with Rett syndrome: a nationwide cross-sectional study in Taiwan. Autism Res 2017;10:1204-14.

39 Xi CY, Lu Y, Tan YH, Hua TY, Zhao YJ, Liu XM, Gao H. Analysis of MECP2 gene copy number in boys with autism. J Child Neurol 2011:26:570-3.

40 Hehr U, Hehr A, Uyanik G, Phelan E, Winkler J, Reardon W. A filamin A splice mutation resulting in a syndrome of facial dysmorphism, periventricular nodular heterotopia, and severe constipation reminiscent of cerebro-fronto-facial syndrome. J Med Genet 2006;43:541-4.

41 Gargiulo A, Auricchio R, Barone MV, Cotugno G, Reardon W, Milla PJ, Ballabio A, Ciccodicola A, Auricchio A. Filamin A is mutated in X-linked chronic idiopathic intestinal pseudo-obstruction with central nervous system involvement. Am J Hum Genet 2007;80:751-8.

42 Heanue TA, Pachnis V. Enteric nervous system development and Hirschsprung's disease: advances in genetic and stem cell studies. Nat Rev Neurosci 2007:8:466-79.

43 Okamoto N, Del Maestro R, Valero R, Monros E, Poo P, Kanemura Y, Yamasaki M, Hydrocephalus YM. Hydrocephalus and Hirschsprung's disease with a mutation of L1CAM. J Hum Genet 2004:49:334-7.

44 Fernández RM, Núñez-Torres R, González-Meneses A, Antiñolo G, Borrego S. Novel association of severe neonatal encephalopathy and Hirschsprung disease in a male with a duplication at the Xq28 region. BMC Med Genet 2010;11:137.

45 Yang T, Ramocki MB, Neul JL, Lu W, Roberts L, Knight J, Ward CS, Zoghbi HY, Kheradmand F, Corry DB. Overexpression of methyl-CpG binding protein 2 impairs TH1 responses. Sci Trans/ Med 2012;4:163ra158.

46 Cronk JC, Herz J, Kim TS, Louveau A, Moser EK, Sharma AK, Smirnov I, Tung KS, Braciale TJ, Kipnis J. Influenza A induces dysfunctional immunity and death in MeCP2overexpressing mice. JCI Insight 2017:2:e88257.

47 Bartsch O, Gebauer K, Lechno S, van Esch H, Froyen G, Bonin M, Seidel J, ThammMücke B, Horn D, Klopocki E, Hertzberg C, Zechner U, Haaf T. Four unrelated patients with Lubs $\mathrm{X}$-linked mental retardation syndrome and different Xq28 duplications. Am J Med Genet A 2010;152A:305-12.

48 Smyk M, Obersztyn E, Nowakowska B, Nawara M, Cheung SW, Mazurczak T, Stankiewicz P, Bocian E. Different-sized duplications of Xq28, including MECP2, in three males with mental retardation, absent or delayed speech, and recurrent infections. Am J Med Genet B Neuropsychiatr Genet 2008;147B:799-806. 